\title{
13. Island Home Country: working with Aboriginal protocols in a documentary film about colonisation and growing up white in Tasmania
}

\author{
JENI THORNLEY
}

Well, how do you become responsible? Well it's simple.

It's like the old traditions where when one Aboriginal group

visited another, they waited at the borderline, the boundary of that cultural country, until they were invited in. ${ }^{1}$

It is through image and fantasy - those orders that figure transgressively on the borders of history and the unconsciousthat Fanon most profoundly evokes the colonial condition. ${ }^{2}$ 


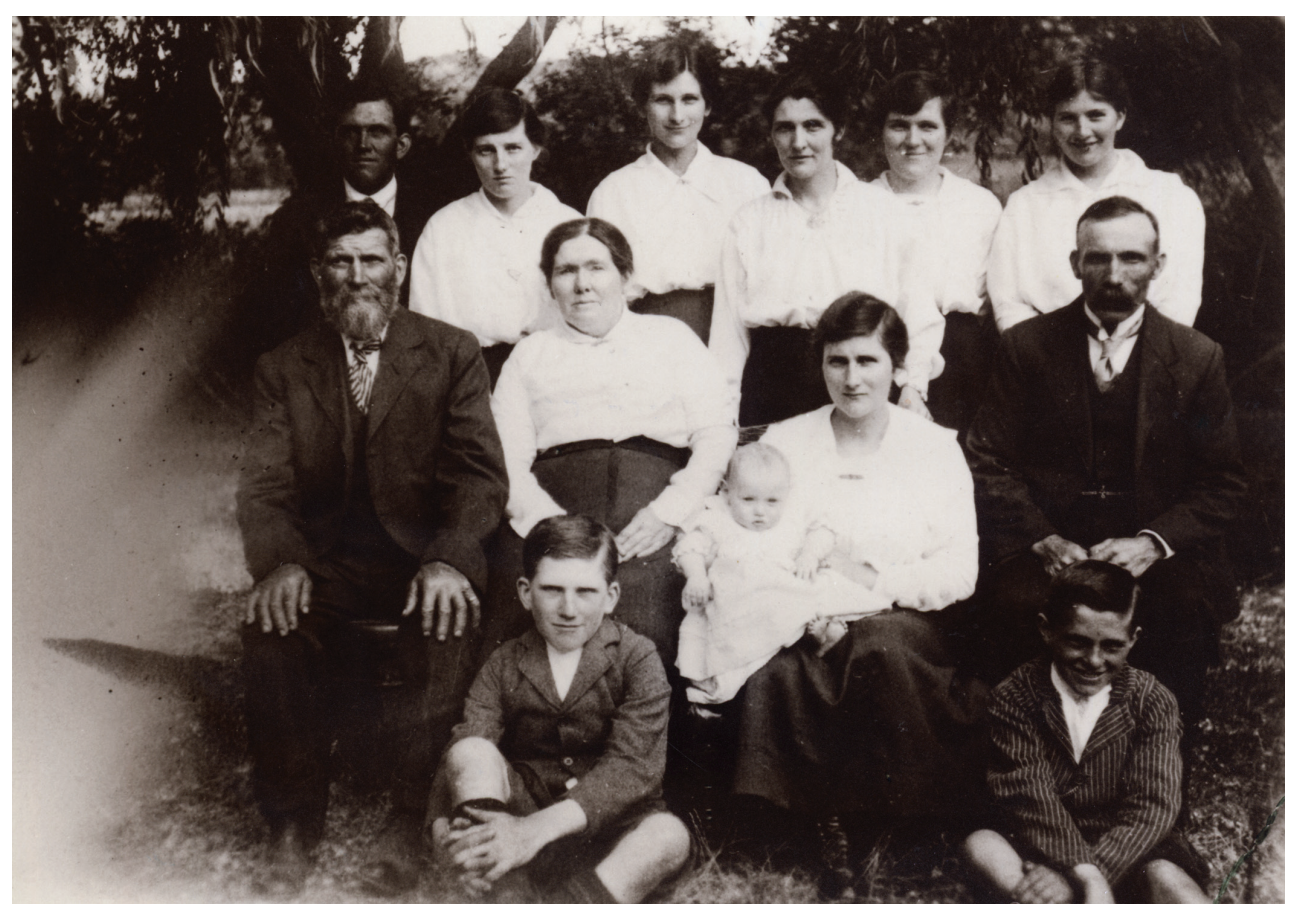

Fig 1. My white Irish Celtic family, Deddington (meenamatta country), Tasmania c1910

'We have been very happy here in the territory of the Nuenone people. Has any one of us paused to do a reckoning? ${ }^{\prime 3}$ In the midst of the 'History Wars' of the early 2000s, these words by historian Cassandra Pybus spoke to me. Born in the late 1940s into an Irish Celtic family, I grew up white in 1950s Tasmania, and knew no Tasmanian Aboriginal people and little of their culture. ${ }^{4}$ Now, more than five decades later, it was time to do my own reckoning. I wanted to penetrate the 'silence' around my childhood imaginary of this island, and then connect it, somehow, to the reality of colonisation - the attempted genocide of the Tasmanian Aboriginal people - and that community's resilient and dynamic struggle to re-establish sovereignty of their country.

So, in 2004 I set off to make a documentary film about these issues. As a filmmaker, I knew film offered ways to consider the past other than simple

3 Pybus 1991: 7.

4 I was of convict stock, transported for theft and dumped by the British into Gadigal country in 1788. The traditional owners of the Sydney City region are the Cadigal band of Port Jackson. Their land stretches from South Head to Petersham. Sam Watson's comments provided a compass to my learning about country: 'Find out the history of the land on which you are living - just find out. And don't use white academic sources, use Aboriginal sources as your primary sources, and find out whose country your on and find out exactly what happened to that mob. Find out what the dreaming stories are, the dances and songs. Then, when you know, that's the first step on the journey of enlightenment'. Watson 2005. 
reliance on the historical record. Film's textual strategies can strongly evoke feeling and emotion, 'affect'. I was mindful of Deleuze's comment: 'if we want to grasp an event we must not show it ... but plunge into it, go through all the geological layers that are its internal history'. ${ }^{5}$ I eventually finished the film, Island Home Country (52 minutes), in 2008. I produced it independently, as part of a Doctorate of Creative Arts degree at the University of Technology, Sydney. ABC Television licensed the film on completion for three broadcasts during 2009-12. Thus, the making of the film was framed by the 'history wars' at the outset and the government's national Apology to Australia's Indigenous Peoples, made by Prime Minister Kevin Rudd in February 2008 at its close.

Filming with my own white family and Tasmanian Aboriginal community members involved ethics and protocols. ${ }^{6}$ As words on paper these might seem clear and direct, but in practice observing proper protocols became a sometimes ambiguous process involving relationship, dialogue, responsibility, trust, and in some situations, lack of trust. This essay discusses how the ensuing 'ethical encounter' with Aboriginal protocols in the filmmaking process affected the film I finally made.

\section{This 'eerie' silence ... of a secret self ${ }^{7}$}

In developing this film project, it became necessary to dig deep into how the idea of a peaceful island, both when I was growing up and later, screened out the reality of Britain's colonial race policies. I needed to think about the amnesia that pervaded Tasmania for so long.

Years prior to making Island Home Country, I saw an eclectic collection of films produced by post-war European filmmakers which explored Nazism, the trauma of the Holocaust, and its repercussions on national identity. ${ }^{8}$ In particular the New German Cinema of the 1960s-1980s erupted into the numbness of postHolocaust Germany. In Stranded Objects: Mourning, Memory and Film in Postwar Germany, Eric Santner draws on Freud's notion that absence is the 'real cause of traumatisation', as he considers the textual strategies these filmmakers developed to 'recuperate affect', to speak into numbness. ${ }^{9}$ He also drew on A and M Mitscherlichs' 1975 psychoanalytic study of the repression of memory

5 Deleuze 1989: 254-255.

6 Everett 2004: <http://www.arts.tas.gov.au/> is the principal protocol document for this project, along with SBS 2004 (draft) Indigenous Protocols, updated by Janke 2009: <http://www.screenaustralia.gov.au/ about_us/pub_indig_protocols.asp > As a DCA at University of Technology Sydney, the project engaged in an approvals process with the UTS Human Research Ethics Committee and Jumbunna, Indigenous House of Learning.

7 Nandy 1999: 308.

8 Night and Fog 1955; Hitler: A Film from Germany 1977; Germany Pale Mother 1980; Heimat 1984; Shoah 1985.

9 Santner 1990: 155. 
of the Holocaust in post-war Germany, a study which laid the groundwork for subsequent research by psychoanalysts, historians and cultural theorists, linking psychoanalytic insights to nation states. ${ }^{10}$

The Mitcherlichs' 'inability to mourn' thesis, I thought, might provide insight into the potential of my film to be a 'work of mourning'. Other scholars have also used the Mitscherlichs' work to help them think about Australian difficulties in coming to terms with the past. Ross Gibson applies it to the repression of 'the bloody past of Australia's colonized frontier', while Bain Attwood suggests that the Australian nation is like Freud's patient who 'resisted having a history'. ${ }^{11}$ Felicity Collins and Therese Davis both utilise psychoanalysis to explore 'shock, recognition and trauma' in Australian films 'after $M a b o o^{\prime}{ }^{12}$ Their work also contributed to my own process, examining resistance or 'blind spots', in my earlier 'pre-Mabo' documentaries. ${ }^{13}$

Psychoanalysis also played a part in producing Island Home Country, not only as a theoretical contribution, but affectively, in my attempts to 'work through' family patterns of madness and recognise in them echoes of Australia's 'Colonial Horror Story' ${ }^{14}$ Perhaps this 'working through' allowed less detritus from my own 'dirty history' to leach into the film's protocols process, or maybe my own family madness generates some kind of porosity, an opening to the colonial nightmare? Such porous private-public-national borders are germane to Aileen Moreton-Robinson's analysis in Duggaibah or 'Place of Whiteness': Australian Feminists and Race. ${ }^{15}$ She investigates how growing up in uncertain, liminal spaces, or amidst cultural difference, may impact on subjectivity, particularly for those interviewees raised in households where a parent's mental illness dominates daily life. Moreton-Robinson suggests that the capacity 'to deploy different subject positions in order to function' may contribute to a more aware inter-cultural subjectivity. ${ }^{16}$ Perhaps, then, my dogged perseverance in the complex inter-cultural space of the film's protocols process was fired in a family member's madness?

\section{Working with Aboriginal protocols}

Non-Aboriginal people have made an enormous number of films about Aboriginal people - ethnographic, documentary and fiction film. ${ }^{17}$ Many of

10 See Najeeb 2002; Rose 2003, 2007; Gilroy 2005; Volkan 2006.

11 Gibson 2002: 50; Attwood 2007: 64.

12 Collins and Davis 2004: 8-9.

13 Maidens 1978, For Love or Money: A History of Women and Work in Australia 1983.

14 Russell 1999: 40.

15 Moreton-Robinson 2000a: 248-250.

16 Moreton-Robinson 2000a: 249.

17 In 1988 Michael Leigh, filmmaker and film archivist, established that more than 6000 ethnographic films had been made about Aboriginal people since the 1890s, the majority by churches and missions, Leigh 
these were made with scant regard for the wishes of the Aboriginal people and communities depicted in them, who increasingly objected. Over time verbal agreements developed into formal written protocols. ${ }^{18}$ At the 1978 Ethnographic Film Conference, held at the Australian Institute for Aboriginal Studies (later AIATSIS), Aboriginal participants turned the tide with a statement of demands for participation in film production, training and distribution, the right to selfrepresentation and a proposed code of ethics. ${ }^{19}$ Later Marcia Langton referred to Eric Michael's 1986 'Primer on restrictions on picture-taking in traditional areas of Aboriginal Australia' as 'the first clear statement of Aboriginal rules on authority over images and the rights to representation'.$^{20}$ Protocols were further developed in 1987 with the Northern Lands Council Protocol, Guess Who's Coming to Dinner in Arnhem Land ? $^{21}$ Since then protocols have become mandatory across filmmaking, art, anthropology, archaeology and sociology and in Indigenous based media organisations. In 2009, after extensive consultations with many communities and organisations across Australia, a new film protocol document Pathways \& Protocols was published, updating earlier film and television protocols. ${ }^{22}$

Protocols have proved to be complex and contentious, and over the last three decades, various commentators have discussed them. During the 1980s both Marcia Langton ${ }^{23}$ and Eric Michaels ${ }^{24}$ considered the intricate issues around representation and the defining of 'Aboriginality', with Langton stressing 'intersubjectivity, when both the Aboriginal and the non-Aboriginal are subjects, not objects ... Can we decolonise our minds? Probably not. But we can try to find ways to undermine the colonial hegemony'.$^{25}$ Recently, NoonuccalQuandamoopah researcher, Karen Martin, argues for the potential of protocols:

A different relationship to self as researcher is articulated in the reframing and redefining of research agreements to give greater agency

1988: 79. There have been many other kinds of film, both documentary and fiction, by non-Aboriginal and Aboriginal filmmakers. As well as the extensive collection of 6000 video titles and 6,500,000 feet of film at AIATSIS: <http://www.aiatsis.gov.au/collections/collections.html $>$, the National Film and Sound Archive has 8319 film and television items about Aboriginal people and 7472 Torres Strait Islander items. The ABC has the largest collection of Aboriginal and Torres Strait Islander footage shot since 1959.

18 Bryson documents the evolution of film protocols at the Australian Institute for Aboriginal Studies (AIAS), with Research Officer Nicholas Peterson's 1969 report detailing his verbal agreements with Aboriginal people and the filming of secret ceremonies. Bryson 2002: 44.

19 Bryson 2002: 65.

20 Langton 1994[1986]: xxxi.

21 Mackinolty and Duffy 1987 reprinted in Langton 1993: 91-92.

22 Janke 2009.

23 Langton 1993.

24 Michaels 1994: 21-27.

25 Langton 1993: 32, 8. 
to the Aboriginal research participants ... This stronger dialogic and selfreflexive researcher role works towards addressing, if not neutralising, issues of power of researcher over researched. ${ }^{26}$

Jennifer Deger develops the concept of intercultural regard in her media collaboration with the Yolgnu community in Gapuwiyak. ${ }^{27}$ In her critical, selfreflexive analysis of the 'anthropology of indigenous media' she examines her own role, as well as discussing contributions by anthropologists, filmmakers and theorists, including David MacDougall, Eric Michaels and Faye Ginsburg who have worked collaboratively with Aboriginal communities over many years. ${ }^{28}$ Others have, however, been more critical. Indigenous filmmaker Frances PetersLittle doubted the use of protocols for film production, suggesting they 'are almost impossible to follow', and Mitchell Rolls sustained a polemical attack on them calling them 'the Messrs Goody-Two-Shoes of Research practices' ${ }^{29}$

Yet without them, what do critics propose? A return to the previous unregulated practice of anything goes? If the producers of the controversial documentary The Last Tasmanian (1978) and Tasmanian Aboriginal communities had negotiated agreed protocols, then the documentary may have been less damaging to the community, or in fact, not made at all. Instead, the film re-enacts what MoretonRobinson calls 'White possession' ${ }^{30}$ It perpetuates the 'ugly' re-assertion that the British genocide of Tasmanian Aboriginal people was achieved, thus evading any discussion of the ongoing 'politics of Aboriginal sovereignty' in Tasmania.

Contrast this film with Black Man's Houses (1992), made 15 years later in Tasmania. Steve Thomas produced the documentary with the Flinders Island Aboriginal Association, and together they make a very different film from The Last Tasmanian. During this film's process, the filmmaker and community seem to have negotiated a collaborative, ethical approach to tell the story of Tasmanian Aboriginal continuity and survival from an Islander perspective. Towards the close of the film, the community re-enact a night funeral at Wybalenna, the transit camp on Flinders Island where so many of their 'Old Ones' died. In the slow, dignified movement of the mourners in the firelight, the drum beating out their loss and pain, we can sense how 'texts must be performed to be experienced'. ${ }^{31}$ This re-enactment and the naming of each gravesite in the Wybalenna Cemetery turn the genocidal thesis of The Last Tasmanian on its head. The repetitive hammering of the grave-stakes into the earth is performative - bringing to consciousness the reality of what happened, at the same time as recuperating

\footnotetext{
26 Martin 2008: 146.

27 Deger 2006: 220.

28 Deger 2006: 34.

29 Peters-Little 2002: 7; Rolls 2003: para 5.

30 Moreton-Robinson 2006: 391.

31 Bruner 1986: 7.
} 
the 'Old Ones' into the present, in a restored genealogy. Not only does Black Man's Houses 'recuperate affect' it seems to have been accepted by community members as a good film.

Black Man's Houses shares a structuring method with Claude Lanzmann's documentary on the Holocaust, Shoah (1985), where the living survivors bear witness to the past in the present. There were clues in both these films for me, suggesting ways I might develop a documentary film about Tasmania from the position of a white settler-invader. Despite the many films made about Aboriginal people across Australia, I could find few where non-Aboriginal filmmakers have considered their own agency as 'white' or as 'newcomers'. Anthropologist and ethnographic filmmaker Eric Michaels, in his collection of essays, Bad Aboriginal Art: Tradition, Media, and Technological Horizons, based on media work with Warlpiri Aboriginal communities of western Central Australia, offers an insightful, theoretical and practice based account of the ethnographer as 'other' and issues around reflexivity. ${ }^{32}$ Rolf de Heer, in his documentary, The Balanda and the Bark Canoes (2006) and anecdotal essay, 'Personal Reflections on Whiteness and Three Film Projects', examines his own attempts to negotiate the complexities of cross-cultural filmmaking. ${ }^{33}$ Although Balanda's narrative strategies, including de Heer's narration, consolidate his identity as the strong auteur in control, while the 'other' remains 'other', something of the intricacy or density of the inter-cultural encounter is conveyed.

\section{Aboriginal control}

Protocols involve communication, negotiation and relatedness, and may be complex and lengthy. All these features of protocols were present in my own filmmaking process. The principal protocol document for me was Respecting Cultures, Working with the Tasmanian Aboriginal Community and Aboriginal Artists. ${ }^{34}$ Several Tasmanian Aboriginal community members, who participated in this project, interpreted the protocols in Respecting Cultures. During the making of the film from 2004 to 2008, as I began to examine my own unconscious assumptions, I realised I had to let go of my control of the project into a process of negotiation and dialogue. There is an inevitable letting go of any imagined or actual 'script' in documentary filmmaking, but this felt different. The process required me to question my ingrained assumptions.

In hindsight, the protocols Aboriginal Control and Continuing Cultures in the Tasmanian Respecting Cultures document, really pushed me to question my motives, further de-centering my control. I had to learn to wait for negotiations 
to unfold in their own time. ${ }^{35}$ In this contested site, as if in the midst of the 'politics of sovereignty', ${ }^{36} \mathrm{I}$ was no longer able to hold the film in my mind. It was slipping away into quicksand. It was not that it was becoming an Aboriginal film; it was more the challenge of whose story is being told here, and who is the storyteller? The protocol process requires time to develop trust in working relationships; it also needs an appropriate film budget, which I did not have. ${ }^{37}$ And why should I be trusted? In the colonised-colonising spaces of Tasmania, this was a challenge - and for good reason, as Tasmanian Aboriginal artist Julie Gough so clearly articulates:

Given our post invasion history of near extinction, Aboriginal people in Tasmania have not been especially keen to share knowledge, information, places, skills, stories with outsiders. We absenced ourselves and were simultaneously removed by the mainstream from everyday Tasmania. We were positioned as doomed or dead - definitely past ... Our shared cross cultural history is an uncomfortable one. Here the grieving and the celebratory avoid each other. ${ }^{38}$

As the years passed by, the reality of the film as a finished work seemed increasingly remote. I sensed a loss of control and a feeling of instability that forced me to shift the gaze further towards myself as 'other'. Fiona Nicoll reflects on a similar process: 'I unlearn what I think I know when I am knocked off my perch ... and hit the ground with a thud ... it does help me to understand Australian race relations within my skin, rather than presuming to know them from some point outside it' ${ }^{39}$

An important moment in the process occurred in 2006 when Julie Gough, whose interview and artworks are in the film, provided a detailed shot-by-shot critique of the film's first edit as part of the protocol, Communication, Consultation and Consent. ${ }^{40}$ Julie also suggested I return to Tasmania to film with more community members. The following year, after further filming with Tasmanian Aboriginal elders Jim Everett and Aunty Phyllis Pitchford, and revised film edits during

35 The Aboriginal Control protocol states, 'Projects involving Aboriginal cultural expression must be negotiated with the owner(s) or Aboriginal community-based organisations, as appropriate'. The Continuing Cultures protocol recommends that, 'An Aboriginal perspective should be sought on all issues surrounding the project...Projects must acknowledge the owner(s) of the cultural heritage and/or expression and satisfy the Tasmanian Aboriginal community on any concerns about the project. These may include: the aims and outcomes; the methodology - the way it will be done; how the results are to be interpreted - the finished/end result; and how it will benefit the Aboriginal community', Everett 2004: 21-24.

36 Moreton-Robinson 2006: 391.

37 A lengthy protocols process is challenging for any 'no-budget film'. Island Home Country took five years requiring a bank loan to complete.

38 Gough 2009.

39 Nicoll 2004: 30 .

40 'Sufficient time should be allocated for consultation and responses. Permission needs to be obtained prior to use of stories, images or creations that might infringe on artists' and communities' ownership or copyright', Everett 2004: 22. 
2007-08, Everett commented: 'I think the storyline should be more yours - looks too much like our story'. ${ }^{41}$ This observation precipitated a turn to my 'white story'. I became the 'unsettled' settler. Finding an embodied visual metaphor to express this white 'other', as well as working through how to 'name' myself, or my family, in speech - in narration - became a challenge.

What to call 'us'? The Tasmanian Aboriginal people I liaised with were direct - 'you can't call yourselves settlers, because you aren't'. Anthropologist WEH Stanner uses the term 'newcomers', ${ }^{42}$ while filmmaker Rachel Perkins describes the colonists as 'strangers' in the First Australians (2008). Germaine Greer turns to the notion of 'Aboriginality as a nationality' for all Australians: 'I was born in an Aboriginal country, therefore I must be considered Aboriginal' ${ }^{43}$ Other writers have suggested that a move to 'belonging' if grounded in responsibility and shared ethics, may offer a way to be here in 'country'. ${ }^{44}$ This is clearly different from belonging to one country, one nation. I wondered which of these terms to adopt for myself. Eventually, through dialogue, internal process and film edit process, I opened the film with - I am white, born on a stolen island - a reflexive sentence of eight words, which took five years to articulate and texturally create in sound and image. This issue of 'naming' is also posed later in narration: What to call us? Invaders, settlers, newcomers? I've heard that Aboriginal Australians called us ghosts.

\section{I am white, born on a stolen island}

As I sought a way to turn the film's gaze onto the interior space of my own colonised-colonising mind, the visual metaphor of myself as a white ghost of Australian history emerged - a floating-fleeing signifier of the traumatic 'affect' of colonisation. This image partly evolved from sensing a thread to PennyX Saxon's eerie, white ghost soldier in her painting, The Hand's of White Man's Destruction, reproduced later in the film. ${ }^{45}$ 


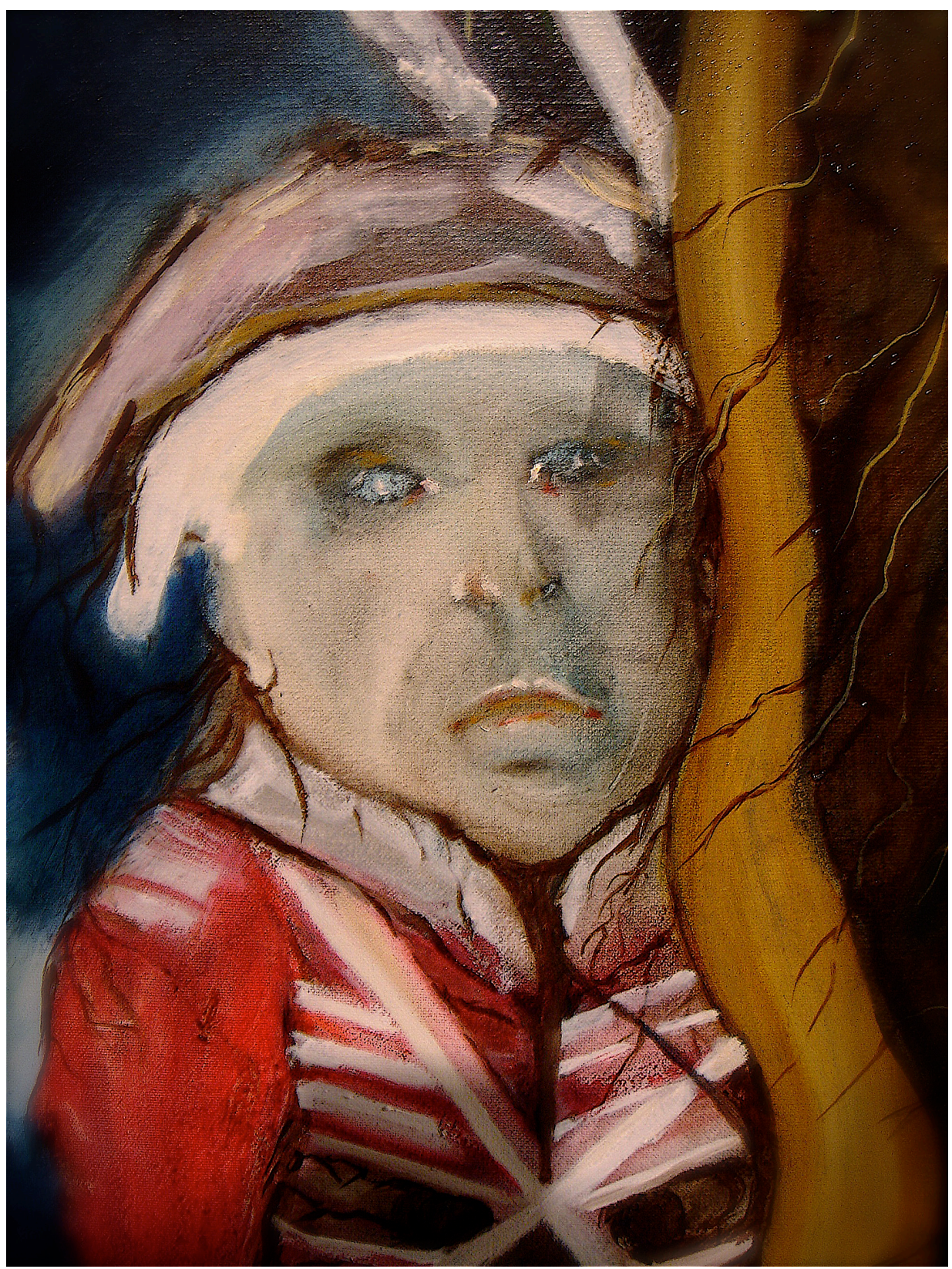

Fig 2. PennyX Saxon, (detail) The Hands of White Man's Destruction, 2006 
This British soldier is half man, half boy. His eyes are vacant, glassy, his mouth fallen - as if he is both witness and accomplice to the inexpressible, to 'the silence'. The British adrift, neither here, nor there, yet enacting white possession, coloniser and colonised, imbricated in each other's minds. I sought out descriptions of white people by Aboriginal writers, as if to experience 'whiteness' through their gaze. Re-reading Mudrooroo Narogin's Dr. Wooreddy's Prescription for Enduring the Ending of the World, it was as if I was reading a description of Saxon's ghost soldier and by implication, my own ghost-self:

The ghost's face, round like the moon, though unscarred, shone pink like the shoulder skin of the early morning sun. Sharp, sea-coloured eyes sought to bridge the gap between them. The ghostly eyes showed such an avid interest in him that he evaded those eyes by staring at the strange skin on the ghost's head. From under it, his hair showed rustcoloured like a vein of red ochre in grey rock. ${ }^{46}$

The opening image of the film thus contains several layers, suggesting the ghostly return of the never-faced 'Possession', or perhaps the ancestral ghost, some say Aboriginal people assumed white-fellas to be. These phantoms imply a restless, uncanny presence, provoking the 'edgy, disturbed, questioning' history discussed by historian Greg Dening. ${ }^{47}$ This ghost exists in a liminal nonspace, a floating signifier of un-settlement. Like Freud's 'uncanny' unheimliche, it evokes no-belonging - being an outsider. ${ }^{48}$ Isaac Deutscher writes about this outsider as a 'non Jewish-Jew':

They lived on the margins or in the nooks and crannies of their respective nations. Each of them was in society and yet not in it, of it and yet not of it. It was this that enabled them to rise in thought above their societies, above their nations, above their times and generations, and strike out mentally into wide new horizons and far into the future. ${ }^{49}$

I think about WEH Stanner's 'analysis of the Australian conscience' where he offers Aboriginal perspectives on the 'ugly deeds' of colonising Australians: ${ }^{50}$

46 Narogin 1983: 29-30.

47 Dening 1998: 220.

48 Freud 1953[1919]: 217-256. See also Ken Gelder and Jane Jacobs for a discussion of 'the post-colonial uncanny' and 'ghost stories' in the Australian context: Gelder and Jacobs 1988: 23.

49 Deutscher 1968: 27.

50 Stanner 1979: 188-189. 
From their point of view we were men from Mars ... we are 'like sharks', meaning that we pursue land, money and goods as sharks pursue little fish; some of it is perhaps very near the bone - as one old man said to me: 'You are very clever people, very hard people, plenty humbug. ${ }^{.51}$

It is as if Stanner is articulating a 'non-Australian' Australian, like Deutscher's 'non Jewish-Jew' or John Docker's 'strangers amongst the nations'. ${ }^{52}$ Martin Nakata in Disciplining the Savages, Savaging the Disciplines takes it furtheroutsiders must 'feel what it is like not to be a 'knower' of this world'. ${ }^{53}$ As any solidity in knowing slips away, I experience un-possession-ghostly unsettlement - on this dislocated colonial-neo-colonial island.

\section{Facing challenges}

One challenge to my white researcher assumptions was Julie Gough's discussion about my possible use of Bishop Nixon's (c1858) photograph of Tasmanian Aboriginal Elders at Oyster Cove. ${ }^{54}$ What right do I have to use this photograph? The photograph is stark and confronting. The Elders carry a defiant gaze, as if to refute Nixon's camera. In the film, I show the photograph to my Aunty. In a later sequence Gough discusses ethics and the protectiveness the community feels towards the Elders and inappropriate use of these photographs. ${ }^{55} \mathrm{I}^{\prime} \mathrm{m}$ between a rock and a hard place. This is a 'messy text'.$^{56} \mathrm{I}$ can't control it. I want to make a film about being a whitey growing up in Tasmania encountering the reality of colonisation, but I'm clumsy and keep putting my foot in it. More than that, the process pushes me to examine my assumptions every step of the way.

There are other challenges, too. During the Colonialism and its Aftermath Conference in Hobart in 2004, another moment shakes my edifice. I present the film's research process in the context of a 'work of mourning'. In the discussion, I was asked: 'What makes you think you're welcome at our mourning sites?' I was surprised. Did I deliver the paper with that assumption? Had I assumed newcomer Australians should somehow be welcomed with open arms at massacres sites? ${ }^{57}$ This direct question really challenged me to think through

\footnotetext{
51 Stanner 1979: 235.

52 Deutscher 1968; Docker 2001: 262.

53 Nakata 2007: 217.

54 Frances Russell Nixon, the first Anglican Bishop of Tasmania, experimented with the newly invented glass plate camera, photographing surviving members of the Tasmanian Aboriginal community, who had been removed from Flinders Island to Oyster Bay, near Hobart in 1847. The photographs are held in the State Library of Tasmania: <http://images.statelibrary.tas.gov.au/> and have been used to signify competing paradigms of Tasmanian history, from the 'doomed race' thesis, as in the documentary film The Last Tasmanian 1978, and more recently as an expression of resilience and sovereignty in the documentary series First Australians 2008. 55 Gough 2008. See also Gough 2004.

56 Marcus 1994: 567.

57 Ryan's The Aboriginal Tasmanians (1981) was an important early influence on my learning about Aboriginal resistance to Britain's violent possession of Tasmania and the imposition of Martial Law in 1828.
} 
the whole premise of this project. It is as if I assumed that the film, as a 'work of mourning', was a worthwhile activity. I had not considered how this might be presumptuous or invasive to the community. I am reminded of the Aboriginal funeral in Jindabyne (2006) when the uninvited whites barge in. I see the comment with fresh insight - we newcomer Australians think we possess the country, the story, and now we want to be in on the mourning sites. Is it an unconscious need for redemption - a case of white 'settlers' trying to make bad settlement history good?

By now, in the film's production process, engaging with protocols is having an intense impact on my childhood memories. The Tasmanian pastoral idyll is breaking down; I understand the land 'grants' and possession of the island as theft in a way I never did as a child. Back then, the island was simply 'home'. In this breakdown of idealised memories, many layers are interacting. There is the impact of the 'revisioning' of Tasmanian history by historians like Lyndall Ryan and Henry Reynolds and their accounts of Tasmanian Aboriginal resistance. ${ }^{58}$ Yet, more powerful is the profound body of work by Tasmanian Aboriginal writers, poets and artists that rush in and 'affect' me. Their collective works offer a way of seeing - a philosophical articulation of 'country' - what Everett writes about as a place in the mind, 'beyond the colonial construct' ${ }^{59}$ Ricky Maynard, too, in his photographs and film, Portrait of a Distant Land, communicates this sense of place - a genealogy of thousands of years - embedded in the way he places his camera in country. ${ }^{60}$

To a white Tasmanian knowing so little of Tasmanian Aboriginal culture or history, these works are like a lightning bolt on the mind. Since reading Ryan's The Aboriginal Tasmanians in 1981 - I had learnt something - and it drew me to make this film. Yet, everything seemed indirect, unlike Sam Watson's counsel to 'use Aboriginal sources as your primary sources' ${ }^{61}$ Subsequently, I read Mollie Mallet and Ida West's autobiographies, Aunty Phyllis Pitchford's poetry, Jim Everett's poetry, essays and political writing, and Greg Lehman's essays. ${ }^{62}$ I also felt a connection with Julie Gough's art works and essays, PennyX Saxon's art works and Ricky Maynard's photography. ${ }^{63}$ Alongside this creative force, were the works of cultural recovery and continuity, documented in Keeping Culture:Aboriginal Tasmania - a collection of essays, art, craft, poetry and song - which expressed the resilience of the Tasmanian Aboriginal community culturally and their fundamental relationship to country. ${ }^{64}$ Coursing through

58 Ryan 1996[1981]; Reynolds 1999, 1995.

59 Everett 2006a: 92.

60 Maynard 2008.

61 Watson 2005

62 Mallet 2001; West 1984; Pitchford 2006; Everett 2006a, 2006b, 2006c; Lehman 1996, 2006.

63 Gough 1998, 2004, 2005; Saxon 2006; Maynard 2008.

64 Reynolds 2006. 
all this, like a raging river, is the ongoing political activism of the Tasmanian Aboriginal Council (TAC) around land rights, repatriation, compensation, languages and sovereignty. It is when all these layers meet 'protocols' - in dialogue with those Tasmanian Aboriginal community members who are prepared to take this white filmmaker on - that I have to confront the question of Who's telling whose story here, and what is 'my story'?

When Julie Gough made her sustained critique of the film's edit, ${ }^{65}$ she showed me images from her installation Whispering Sands - haunting, ghostly figures of nineteenth century British collectors of Tasmanian Aboriginal people and culture. ${ }^{66}$

I wondered, am I like one of those collectors? Maybe she is suggesting I am. I feel paranoid now. Was I collecting Aboriginal stories, like filmmaker Chris Marker's 'bounty hunter' in his essay film Sans Soleil (1983), yet without the ironic distance that Marker deploys to get himself both in and out of his own film? My unstable feelings around being a white person making this film take a greater hold. I try and work this instability back into the fabric of the film.

My attempt to defer narrative authority in a multi-vocal film had become increasingly difficult with Jim Everett's injunction that I tell my story, not theirs. Later Aunty Phyl suggests, 'just make sure it's your voice speaking, so it's really clear it's a film about you' ${ }^{67}$

I am thrown further into myself as a white 'other'. Yet in this process, a shift is also taking place - from the project as an imaginary artefact in my own mind, or words on a page - to relationships with people in the present. To be present and grounded in what is happening seems to involve a shift from introspection, to what Aboriginal philosopher and lawyer Irene Watson describes as 'a meditation on discomfort', to considering questions such as the lawfulness of settler Australia. ${ }^{68}$ The focus of the project shifts from being a 'mourning work' towards articulating an intense experience of Australia's race relations within my skin. ${ }^{69}$

65 Gough, pers comm, 2006.

66 Gough 1998.

67 Pitchford, pers comm, 2008.

68 Watson 2007: 30.

69 Nicoll 2004: 30. 


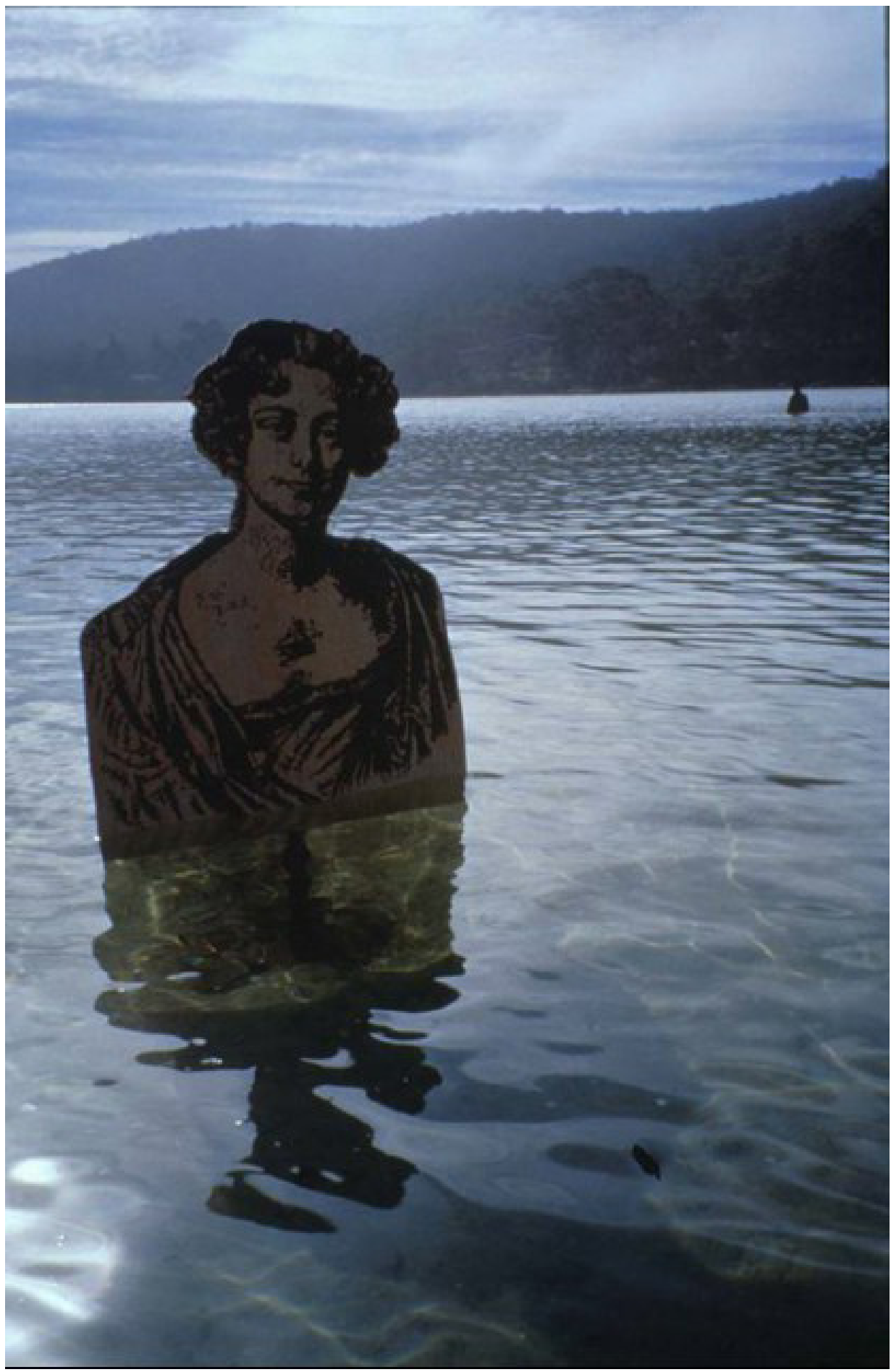

Fig 3. Julie Gough, The Whispering Sands (Ebb Tide), 1998 


\section{On the borders of history and the unconscious}

Literature, art and film ... can be particularly useful to critical race theory because their images, tones, and, textures often perform subtle emotional work that richly engages the nonreflective aspects of white privilege. ${ }^{70}$

The invisibility of whiteness was laid down so deep in my unconscious that it was not until my direct 'engagement with an Indigenous critical gaze' in the film's protocols process, that it was exposed. ${ }^{71}$ To dig into unconscious patterns is not easy. Resistance is rife. Cathryn McConaghy discusses the reactions of a class of student teachers to a screening of Rabbit Proof Fence (2002). ${ }^{72}$ McConaghy explores what happened in the classroom in the context of Freud's 'repetition compulsion' and his notion of 'mourning and melancholia' and 'intergenerational trauma' in both survivors and perpetrators. ${ }^{73}$ One third of the students walk out. The screening is intensified by the presence of Veronika $B$, a Stolen Generation survivor who introduces the film and links it to her own experience. McConaghy observes one non-Indigenous student's response as profoundly ambivalent, an 'excess of trauma ... split between being the accuser and the accused, between reproach of others and self-reproach'. The presence of Veronika B. connects this student 'with her fears about being engulfed by the trauma of Australian existence'.$^{74}$

There is a connection here to Homi Bhabha's discussion of the way Franz Fanon's 'psychoanalytic framework illuminates the 'madness' of racism' - lying unexamined in the psyche. ${ }^{75}$ His notion that the imaginary and the performative offer ways to work through the effects of colonial-post-colonial political power, assists my own 'deliberate act of mental decolonisation' ${ }^{76}$

\section{'Images recuperate affect' ${ }^{\prime 7}$}

Across time, space, and cultures Julie Gough's 'Transmitting Device' surfaces. ${ }^{78}$

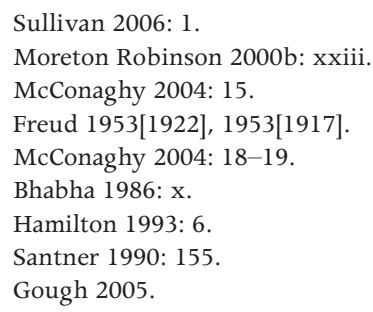




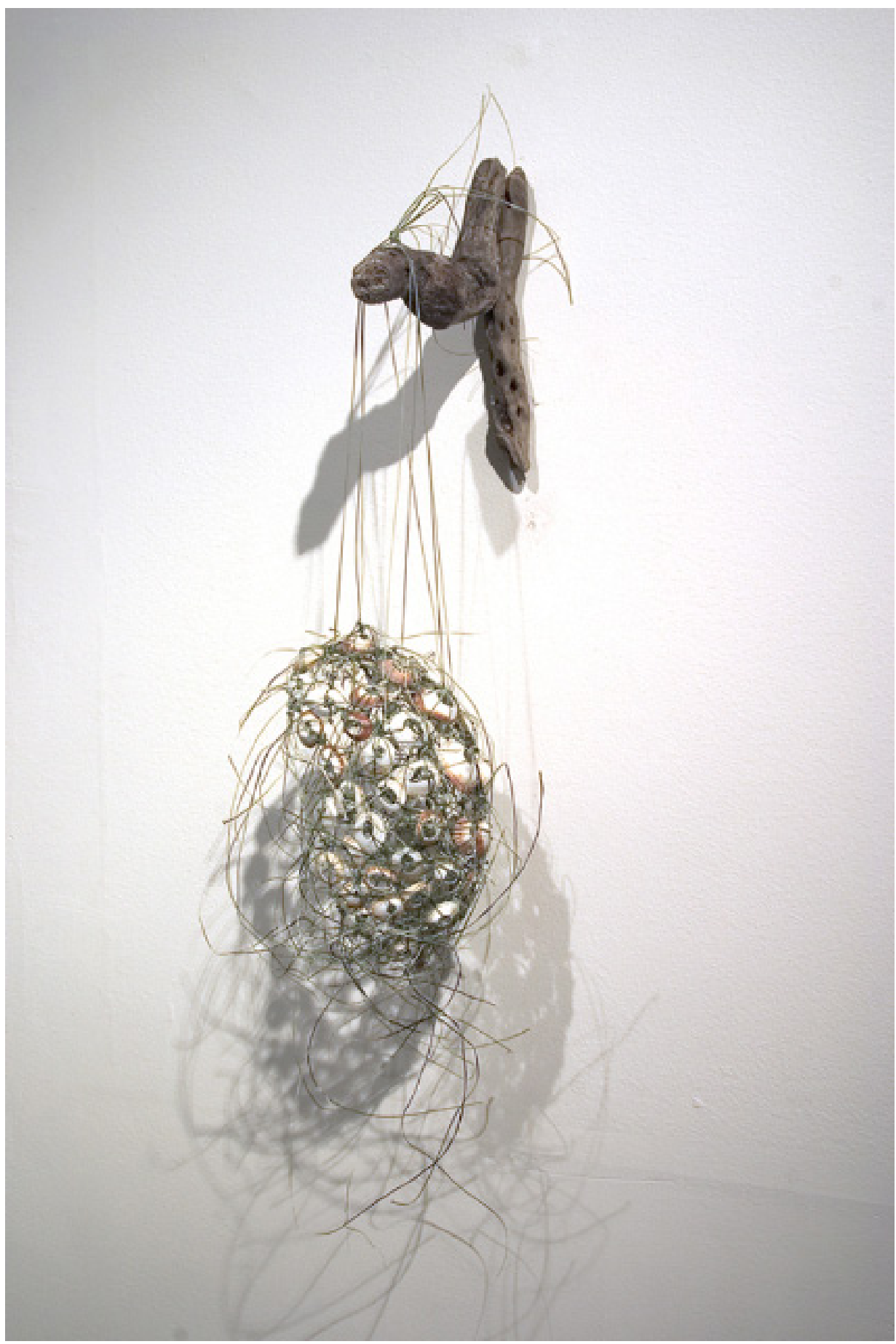

Fig 4. Julie Gough, Transmitting Device, 2005 
This delicate sculpture, constructed from Lomandra longifolia and limpet shells made into a headdress, carries echoes of a mourning cap. Beyond words, the artist reaches back and 'transmits', across time, the living presence of her culture. Gough invents a metaphor, an artefact for now and the future: a listening device, a ceremonial container to protect the internal mind of her culture - as sovereign space. It transmits what the 'white possession' tried to annihilate, yet what is always in a continuous process of becoming.

We can sense this force of 'continuous process' in Darlene Mansell's charged words in her interview in the documentary series First Australians (2008). ${ }^{79}$ Mansell's piercing address, direct to camera: 'There will never ever be no Tasmanian Aboriginal people, never, ever', transmits 'affect' way beyond the square frame of any television screen. 'Affect' moves, it touches us. It is mysterious, trembling - alive. Mansell challenges the 'western' screen of denialism, colliding past into present - asserting sovereignty.

Homi Bhabha discusses the 'houses of racial memory' and 'the unspoken, unrepresented pasts that haunt the historical present'. ${ }^{80}$ In Tasmania, as I filmed, the past seemed to be present in absence. As I searched the ruins of my own memory, I scrutinised old photographs for clues, like the one of my sister and me in fancy dress:

I'm the pixie, my sister in - 'black face'. Who is she supposed to be and who dreamt up that costume? The photograph carries a 'trace' of the real - a hint of race. Sitting with this photograph - being with it, in duration, a process starts. We may call it 'affect', 'memory shock', or 'aura', whatever, but something is taking place, an invocation to the act of looking - Roland Barthes' 'punctum' ${ }^{81}$ The photograph 'pricks' me. It disturbs, unsettles. As I edit it into the film there is a sudden rush of memories into the present - yet no space in the film edit for the narrative detail this photograph evokes so intensely from the past. ${ }^{82}$

\footnotetext{
79 Mansell 2008.

80 Bhabha 2007: 18.

81 Barthes 1981: 27.

82 Sitting with particular photographs may precipitate a stream of memory and affect, as in Barthes' response to the photograph of his mother: Barthes 1981: 67-72. See also Annette Kuhn's Family Secrets, a study of photographs and the performative nature of remembering: Kuhn 1995: 158.
} 


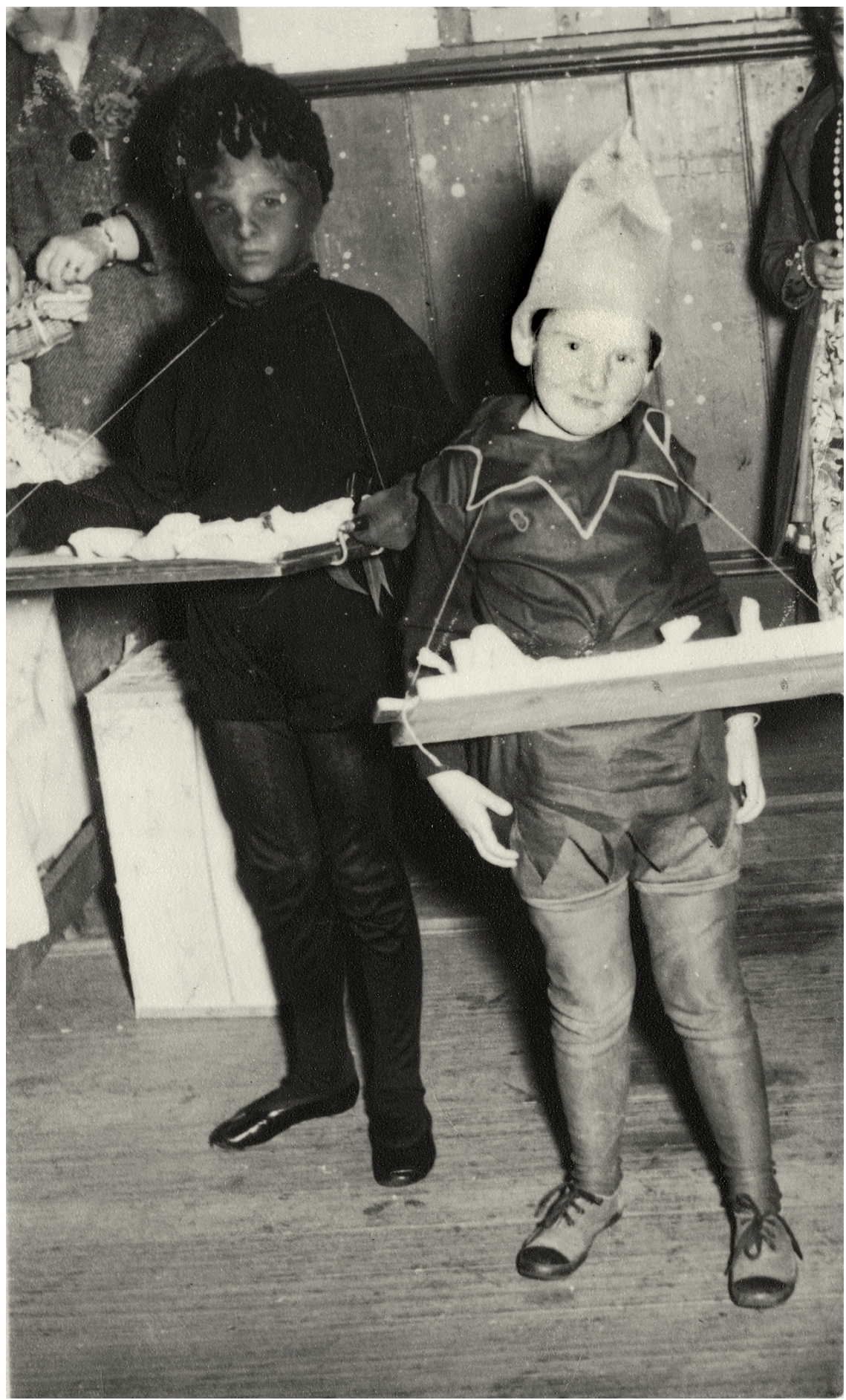

Fig 5. St Georges Church Fete, Launceston 1954 


\section{Memories}

There was a fancy dress competition every year at Nana's church. We carried our trays, with the sweets spread out - Turkish delight, pink and white coconut roughs, bright red toffee apples. We walked through the crowd, selling our baskets for $3 \mathrm{~d}$ each. The string around the tray was rough and chafed my neck. It was hot and noisy in the crowd and the faces were red and their eyes bulgy. They pinched our cheeks between their fingers and said, 'Ila's dear granddaughters'. My sister had a black sheer stocking over her face with black woollen hair sewn in curly rings. Was she dressed as an Aboriginal person? I think she felt strange wearing it, because through her stocking face she never smiled. The stories of the Tasmanian Aboriginal people were never spoken then - not by a soul. Yet there she was in this costume. And still the silence. The secret. Then she won first prize for best costume and they took the photograph. Everyone was saying smile, but she couldn't. It was hot and my mouth was dry and I felt I might cry. All I wanted was a ginger beer in a bottle with a paper straw. It had a spicy taste, but was nice.

\section{We grew up behind a hedge, keeping history out}

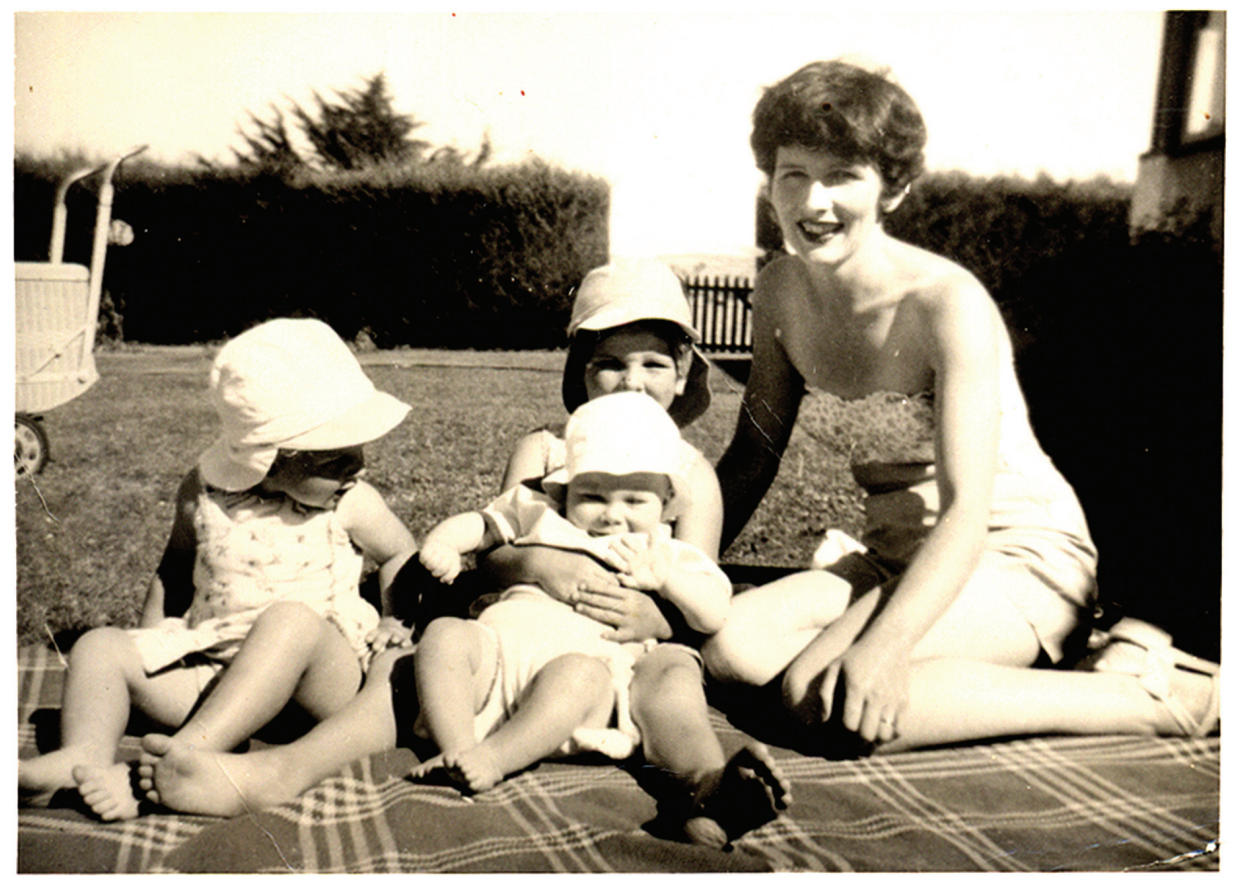

Fig 6. The Midlands Tasmania c1952 
January 1981. Uncle R said to me, while on a visit to the sheep farm, 'What are you going to Cape Barren for? There's nothing there'. His words were delivered hard, like his weathered, red face. The words were code. Don't you go digging around. Don't mess with history. Tasmania's white. There are no blacks (left). This moment in the sunroom, the pale winter's light filtering through the drawn blinds - the emerald green hedge surrounding the farmhouse like a barricade is a memory I can touch with my fingers. Aunty is about to push the trolley down the corridor with afternoon tea and cake. Everything hangs suspended in space, adrift, time standing still. The distant, denuded barren hills, the dying sheep farm, the phosphate-layered soil - a dead weight around my neck, strangling me. This moment holds my childhood on the island. Keep your mouth shut. Your mind shut. This is amnesia, forced forgetting. Woe betide if you break the lock. Outside in the car, my closely read copy of Lyndall Ryan's just published, The Aboriginal Tasmanians. The next day, on Flinders Island, at Wybalenna, sitting with Lyndall, she reads from her book:

For Flinders Island was now a ration station to a remnant group of people from whom the most able and the most healthy had been removed. Supply ships still failed to arrive at regular intervals, many of the Aborigines still could not stomach salt meat, and on a clear day a number of women would sit on Flagstaff Hill and look across to the north-east coast of Van Diemen's Land ninety kilometres away and lament the loss of their country ... At night they performed ceremonial dancing and by day they went hunting for mutton birds and shellfish without ... permission. ${ }^{83}$

In that moment my mind opened up to 'the secret' on this island where I was born. I knew that I would try and make a film about the fissure revealed then this mighty space between past and present. 'Deep history' ${ }^{84}$

\section{The narcissism of white}

Ann Curthoys, in her 1999 article Expulsion, Exodus and Exile in White Australian Historical Mythology, prises the scab off the white wound to get a good look at the messy knot of complex emotions layered beneath the surface. She writes about the victim mentality in the white settler community's sense of homeland and the way victimological narratives take form: 'the trauma of expulsion, exodus, and exile obscures empathetic recognition of indigenous perspectives, of the trauma of invasion, institutionalisation, and dispersal' ${ }^{85}$ I read this early on in the film's research phase. It offered ways to think about

83 Ryan 1996[1981]: 196-197.

84 Lehman 2006. See also Dening 1998.

85 Curthoys 1999: 18. 
the 'subject position' of the white settler - how being a victim occupied centre stage in the 'white Australian' historical narrative. It resonated, too, with my own family in Tasmania - no one ever talked about Aborigines, and there was an ingrained sense of our own hardship.

If unconscious, the white wound bleeds relentlessly, as Curthoys discusses in the white nation's foundation myths - the suffering on the land, the white child lost in the bush, the heroic but failed explorers, the wounded soldier, the pain of Gallipoli, ${ }^{86}$ and now my own narrative construction - anxious white filmmaker. ${ }^{87}$ Ghassan Hage intimates, when 'Whiteness is ... a field of accumulating Whiteness', there is a danger. ${ }^{88}$ He suggests whiteness reinforces its own 'mastery', perpetuating 'a fantasy of White supremacy'. ${ }^{89}$ In narrating my own whiteness as a ghostly performance I am aware of Sara Ahmed's penetrating analysis, that such declarations may be 'unhappy performatives'.$^{90}$ Anti-racism, she argues, is not performative, it may simply reproduce white privilege: 'What does such an anxious whiteness do?'91

The instability of whiteness is a fluid, uncertain space - uncomfortable - a space where change might happen, or not. It is a space where this privileged, consolidated white colonial invader-settler is pushed into unsettlement, into being strange, into becoming 'other' - to what Judith Butler calls, 'the strange fecundity of that wreckage' ${ }^{92}$ I did not set off to make a film about myself; I wanted originally to examine Tasmanian historical amnesia. Yet the protocols process around Communication, Consultation, Consent and Aboriginal Control push the film irrevocably to come from my speaking position - whiteness.

\section{Borderline}

This place of being strange is a place to inhabit, to feel, to listen from and to be speech-less. As Ahmed explores, 'To hear the work of exposure requires that white subjects inhabit the critique, with its lengthy duration' ${ }^{93}$ In deconstructing 'possession' another 'possession' is forming - these words on the page now, the film itself - both forms of possession, holding the reins of story. Despite

\footnotetext{
86 Curthoys 1999: 3-13.

87 Katrina Schlunke made this observation in her capacity as co-doctoral supervisor to the project: Schlunke, pers comm, 2008. It helped me link my performance of 'anxious whiteness' to the white victim analysis developed by Curthoys.

88 Hage 1998: 58

89 Hage 1998: 18.

90 Ahmed 2004: para 50.

91 Ahmed 2004: para 6.

92 Butler 2003: 469.

93 Ahmed 2004: para 57.
} 
my attempts to be self-reflexive and explicate something of the negotiated protocols process in the film, Ahmed's questions reverberate. Does the film 'block hearing'?'

I sit and listen to Vernon Ah Kee's passionate critique as he talks the audience through his powerful art works, which deconstruct anthropologist Norman Tindale's colonist gaze. ${ }^{95}$

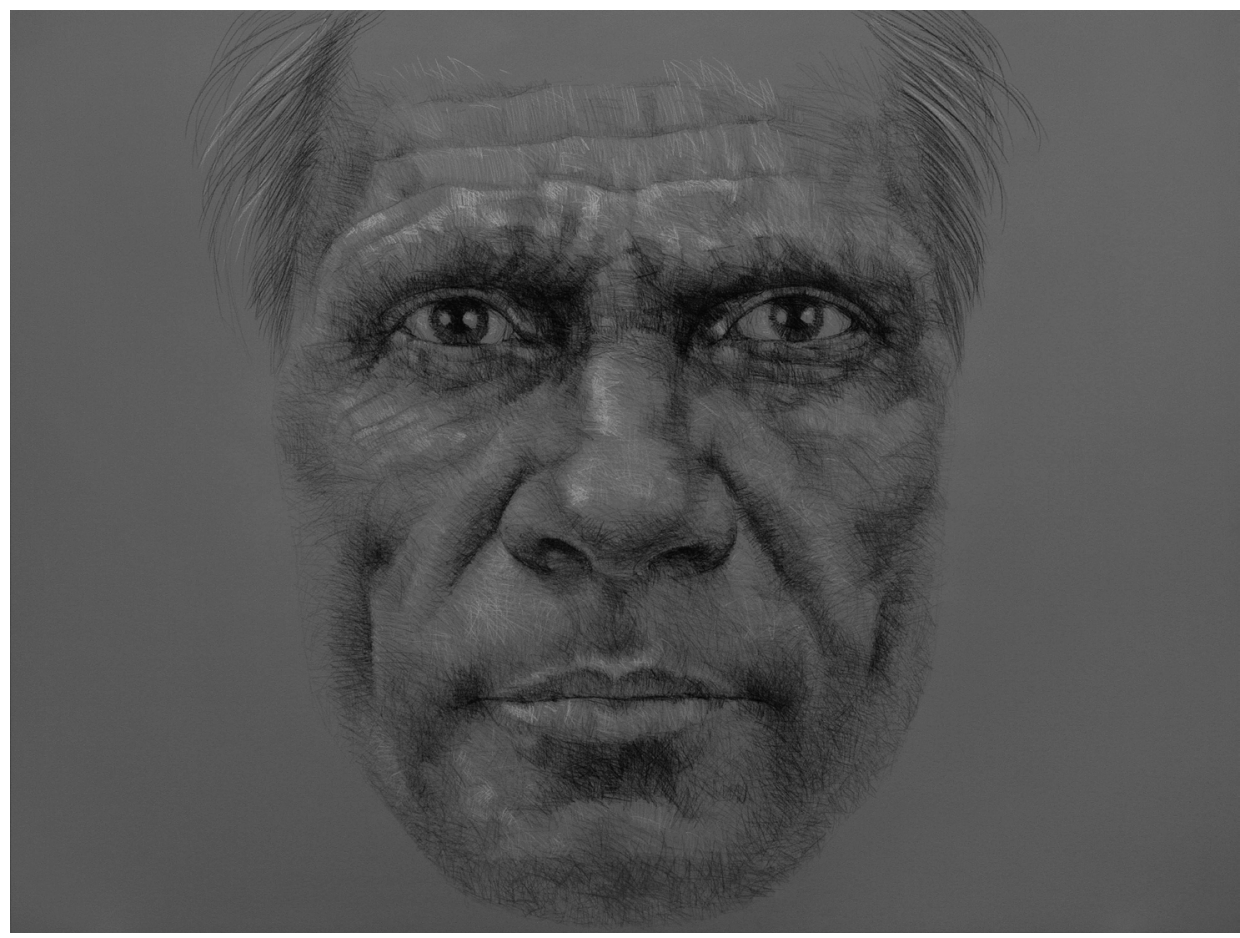

Fig 7. Vernon Ah Kee, George Sibley, 2008

Acrylic, charcoal and crayon on canvas, $180 \times 240 \mathrm{~cm}$, Private collection, Brisbane. Courtesy the artist and Milani Gallery, Brisbane

I try to stay open to his rage. Sometimes I close my eyes to hear the ebb and flow in his voice - now gentle, insightful about his art practice - then Ah Kee shifts to another register, anger spilling out against white privilege. To listen and stay open I have to separate out my pain around Dad's angry violence in our family, from Ah Kee's intense feelings around white racist oppression.

94 Ahmed 2004: para 56

95 Ah Kee 2008a. 
we pondered whether black folks and white folks can ever be subjects together if white people remain unable to hear black rage ... A black person unashamed of her rage, using it as a catalyst to develop critical consciousness, to come to full decolonized self actualisation. ${ }^{96}$

At the borderline of becoming 'other' emerges exposure, inside this white skin, learning to listen, stay open and pass through 'anxious whiteness'. Ahmed writes about a 'double turn ... for white subjects ... to stay implicated in what they critique ... their role and responsibilities in these histories of racism ... to turn away from themselves and towards others' ${ }^{97}$ In this unsettling process, there is a shift from the personal, the individual - towards community.

\section{Conclusion}

Thinking about this Island Home Country project, then, not as 'some creativity capacity of the mind', as Stephen Muecke puts it, but more as 'the practice of visiting country and its associated ethics ... a visitor in Aboriginal country', I am reminded of the 'visiting protocols' I encountered along my way in Tasmania. ${ }^{98}$ 'It's simple', says Jim Everett, 'It's like the old traditions where one Aboriginal group visited another, they waited at the borderline, at the boundary of that tribal country until they were invited in' ${ }^{99}$

In this unsettling space of becoming 'other', while at the same time working through the protocols Benefit to Community and Proper Returns, there are challenges. ${ }^{100}$ The term reckoning does not fit this 'double turn'. As in Jacques Derrida's ruminations on 'there shall be no mourning', ${ }^{101}$ in 'post Apology' Australia there shall be no reckoning - not any time soon - while we newcomers learn to be in what Irene Watson calls, 'a meditation on discomfort'. ${ }^{102}$ This is not a passive process. It is about listening, along with responsibilities in the here and now. As 'newcomers', this uncomfortable meditation may move us to face the implications for our actions in the present and the future of 'our' illegal sovereign status.

\footnotetext{
96 bell hooks 1995: 12, 16.

97 Ahmed 2004: para 59.

98 Muecke 2008: 80-81, 84.

99 Everett 2008.

100 A percentage of Island Home Country's returns go to the Tasmanian Aboriginal Land and Sea Council's, Aboriginal Land Management Team. Returns to the Tasmanian Aboriginal artists whose work is in the film were paid from the ABC license fee. The ATOM Study Guide and DVD provide an educational resource to secondary and tertiary sectors and is available at: <http://www.jenithornley.com $>$ and The Education Shop: $<$ http://www.theeducationshop.com.au>

101 Derrida 2001: 211-242.

102 Watson 2007: 30.
} 


\section{Acknowledgments}

A heartfelt thanks to Aunty Phyllis Pitchford, Jim Everett, Julie Gough and PennyX Saxon for sharing protocols process with me; Vicki Grieves for lively discussions around history and Indigenous philosophy; a special thanks to UTS doctoral supervisors Sarah Gibson, Katrina Schlunke, Heather Goodall, production supervisor Toula Anastas; and to Judy Spielman, Stephen Ginsborg and my family for their involvement.

\section{References}

Ah Kee, V 2008a, 'Framing Race Politics and Identity in the Visual Arts', Jumbunna Indigenous House of Learning Annual Lecture, October 2008, University of Technology Sydney, Sydney.

- 2008b, 'What is an Aborigine', (installation of 12 paintings), Cockatoo Island, 16th Biennale of Sydney.

Ahmed, S 2004, 'Declarations of whiteness: the non-performativity of antiracism', Borderlands e-journal 3: 2, accessed 29 December 2008: <http://www. borderlands.net.au/vol3no2_2004/ahmed_declarations.htm>

Attwood, B 2007, 'The Australian patient: traumatic pasts and the work of history', in The Geography of Meanings: Psychoanalytic Perspectives on Place, Space, Land and Dislocation, MT Savio Hooke and S Akhtar (eds), International Psychoanalytical Association, London: 63-78.

Barthes, R 1981, Camera Lucida: Reflections on Photography, Farrar, Straus \& Giroux, New York.

bell hooks 1995, Killing Rage: Ending Racism, Henry Holt \& Co, New York.

Bhabha, H 1986, 'Foreword, Remembering Fanon: self, psyche, and the colonial condition', in Black Skin, White Masks, F. Fanon, Pluto Press, London: vii-xxxv.

- 2007, The Location of Culture, F Fanon, Routledge, London.

Bruner, E 1986, 'Experience and its expressions' in The Anthropology of Experience, VW Turner and EM Bruner (eds), University of Illinois Press, Urbana: 3-32.

Bryson, I 2002, Bringing to Light: A History of Ethnographic Film-Making at AIATSIS, AIATSIS Press, Canberra. 
Passionate Histories

Butler, J 2003, 'Afterword: After loss, what then?' in Loss, The Politics of Mourning, D Eng and D Kazanjian (eds), University of California Press, Berkeley: 467-473.

Curthoys, A 1999, 'Expulsion, exodus and exile in white Australian historical mythology', Journal of Australian Studies 61: 1-18.

Collins, F and T Davis 2004, Australian Cinema After Mabo, Cambridge University Press, Cambridge.

Colonialism and Its Aftermath: An Interdisciplinary Conference 2004, University of Tasmania, Hobart.

Deger, J 2006, Shimmering Screens: Making Media in an Aboriginal Community, Visible Evidence 19, University of Minnesota Press, Minneapolis.

Deleuze, G 1989, Cinema 2: The Time Image, University of Minnesota Press, Minneapolis.

Dening, G 1998, Readings/Writings, Melbourne University Press, Melbourne.

de Heer, R 2007, 'Personal reflections on Whiteness and three film projects', Australian Humanities Review 42, accessed 9 December 2008: <http://www. australianhumanitiesreview.org/archive/Issue-August-September \% 202007/ Deheer.html>

Derrida, J 2001, 'Jean-Francois Lyotard (1924-98) all-out friendship', in The Work of Mourning, PA Brault and M Naas (eds), University of Chicago Press, Chicago: 211-241.

Deutscher, I 1968, The Non-Jewish Jew and Other Essays, Merlin Press, London.

Docker, J 2001, 1492 Poetics of Diaspora, Continuum, London.

Everett, Jim 2004, Respecting Cultures: Working with the Tasmanian Aboriginal Community and Aboriginal Artists, Aboriginal Advisory Committee, Arts Tasmania, Hobart, available at: <http://www.arts.tas.gov.au/>

- 2006a, 'This is Manalargenna country', in Keeping Culture: Aboriginal Tasmania, A Reynolds (ed), National Museum of Australia Press, Canberra: 89-97.

— 2006b, Meenamatta Water Country Discussion, with J Kimberley, Bett Gallery, Hobart.

- 2006c, 'Dispossession' in Memory, Moments and Museums, M Lake (ed), Melbourne University Press, Melbourne: 215-227. 
— 2008, Interview in Island Home Country (DVD), Anandi Films, Sydney.

Fanon, F 1986, Black Skin, White Masks, Pluto Press, London.

Freud, S 1953[1917], Mourning and Melancholia, SE 14, Hogarth Press, London: 243-258.

— 1953[1919], The Uncanny, SE 17, Hogarth Press, London: 217-256.

- 1953[1922], Beyond the Pleasure Principle, SE 18, Hogarth Press, London: 7-64.

Gelder, K and J Jacobs 1998, Uncanny Australia: Sacredness and Identity in a Postcolonial Nation, Melbourne University Press, Melbourne.

Gilroy, P 2005, Postcolonial Melancholia, Columbia University Press, New York.

Gibson, R 2002, Seven Versions of an Australian Badland, University of Queensland Press, St Lucia, Queensland.

Gough, J 1998, The Whispering Sands (Ebb Tide) (installation), Sculpture by the Sea, Eaglehawk Neck Bay, Tasman Peninsula.

- 2004, 'Voices and sources - making art and Tasmanian Aboriginal history', Colonialism and Its Aftermath, An Interdisciplinary Conference, University of Tasmania, Hobart.

— 2005, Transmitting Device (sculpture), Gallery Gabrielle Pizzi, Melbourne.

- 2008, Interview in Island Home Country, (DVD), Anandi Films, Sydney.

— 2009, 'Living in the past. An Aboriginal artist's experience of being Tasmanian', Perspectives on Urban Life: Connections and Reconnections, AIATSIS National Indigenous Studies Conference, Australian National University, Canberra, 29 September-1 October, accessed 21 February 2010: <http://www.aiatsis.gov.au/ research/conf2009/papers/R1.2.html>

Graham, M 1999, 'Some thoughts about the philosophical underpinnings of Aboriginal worldviews', Worldviews: Environment, Culture and Religion 3: 105118.

Greer, G 2003, 'Whitefella jump up: The shortest way to nationhood', Quarterly Essay 11: 1-78.

Hage, G 1998, White Nation: Fantasies of White Supremacy in a Multicultural Society, Pluto Press, Sydney. 
Hamilton, A 1993, Foreword, in 'Well, I heard it on the Radio and I saw it on the Television...', M Langton, Australian Film Commission, Sydney: 5-6.

Janke, T 2009, Pathways \& Protocols: A Filmmaker's Guide to Working with Indigenous People, Culture and Concepts, Screen Australia, Sydney, available at: <http://www.screenaustralia.gov.au/about_us/pub_indig_protocols.asp >

Khun, A 1995, Family Secrets: Acts of Memory and Imagination, Verso, London.

Langton, M 1993, 'Well, I heard it on the Radio and I saw it on the Television...': An essay for the Australian Film Commission on the politics and aesthetics of filmmaking by and about Aboriginal people and things, Australian Film Commission, Sydney.

- 1994[1986], 'Introduction', in Bad Aboriginal Art, Tradition, Media, and Technological Horizons, E Michaels, University of Minnesota Press, Minneapolis: xxvii-xxxvi.

Lehman, G 1996, 'Life's quiet companion', Island 69: 54-61.

- 2006, 'Beneath the Still Waters: connecting with Tasmania's deep history in Sullivans Cove', Conversations in the Cove, Sullivans Cove Waterfront Authority, Hobart: 2-8.

Leigh, M 1988, 'Curiouser and Curiouser', in Back of Beyond: Discovering Australian Film and Television, Australian Film Commission, Sydney: 78-89.

McConaghy, C 2004. 'Linda C. and the Terrors of the Rabbit-Proof Fence', English Studies in Canada 30(2): 13-20.

Mackinolty, C and Duffy 1987, Guess Who's Coming to Dinner in Arnhem Land?, Northern Land Council, Darwin.

Mallet, M 2001, My Past, their Future: Stories from Cape Barren Island, Blubber Head Press and Riawunna Centre for Aboriginal Education, Sandy Bay, Tasmania.

Mansell, D 2008, Interview in First Australians, Episode 2 (documentary series), Blackfella Films, Sydney.

Marcus, GE 1994, 'What comes (just) after "Post"? The case of ethnography', in The Handbook of Qualitative Research, NK Denzin and YS Lincoln (eds), Sage, Thousand Oaks, CA: 563-574.

Martin, K 2008, Please Knock Before You Enter: Aboriginal regulation of Outsiders and the Implications for Researchers, Post Pressed, Teneriffe, Queensland.

Maynard, R 2008, Ricky Maynard: Portrait of a Distant Land (exhibition of 60 photographs), Museum of Contemporary Art, Sydney. 
Michaels, E 1994[1986], Bad Aboriginal Art: Tradition, Media, and Technological Horizons, University of Minnesota Press, Minneapolis.

- 1994[1986], 'Primer on restrictions on picture-taking in traditional areas of Aboriginal Australia', in Bad Aboriginal Art: Tradition, Media, and Technological Horizons, University of Minnesota Press, Minneapolis: 1-18.

Mitscherlich, A and M 1975, The Inability to Mourn: Principles of Collective Behaviour, Tavistock, London.

Moreton-Robinson, A 2000a, 'Duggaibah or "Place of Whiteness": Australian feminists and race', in Race,Colour and Identity in Australia and New Zealand, J Docker and G Fischer (eds), University of New South Wales Press, Sydney: 240-255.

- 2000b, Talkin' Up to the White Woman: Aboriginal Women and Feminism, University of Queensland Press, Brisbane.

— 2006, 'Towards a new research agenda?: Foucault, Whiteness and Indigenous sovereignty', Journal of Sociology 42(4): 383-395.

Muecke, S 2008, 'A chance to hear a Nyigina song', in Joe in the Andamans: and other Fictocritical Stories, Local Consumption Papers, Sydney: 80-93.

Najeeb, S 2002, 'Circles in the Dust', Psychoanalysis Down Under 2, accessed 21 September 2009: <http://www.psychoanalysisdownunder.com/downunder/ backissues/issue2/112/circles_in_dust>

Nakata, M 2007, Disciplining the Savages, Savaging the Disciplines, Aboriginal Studies Press, Canberra.

Nandy, A 1999, 'The invisible holocaust and the journey as an exodus: the poisoned village and the stranger city', Postcolonial Studies 2(3): 305-329.

Narogin, M (C Johnson) 1983, Dr. Wooreddy's Prescription for Enduring the Ending of the World, Hyland House, Melbourne.

Nicoll, F 2004, 'Reconciliation in and out of perspective: white knowing, seeing, curating and being at home in and against Indigenous sovereignty', in Whitening Race, A Moreton-Robinson (ed), Aboriginal Studies Press, Canberra: 17-32.

Nixon FR (Bishop) c1858, Aborigines of Tasmania (photograph), Allport Library and Museum of Fine Arts, State Library of Tasmania, Hobart.

Peters-Little, F 2002, 'On the impossibility of pleasing everyone: the legitimate role of white filmmakers making black films', Art Monthly 149: 5-9. 
Passionate Histories

Pitchford, P 2006, "“Our tally": a day's birdin' through the eyes of a child', in Keeping Culture: Aboriginal Tasmania, AJ Reynolds (ed), National Museum of Australia Press, Canberra: 59-67.

Pybus, C 1991, Community of Thieves, Minerva, Melbourne.

Read, P 2000, Belonging: Australians, Place and Aboriginal Ownership, Cambridge University Press, Cambridge.

Reynolds, AJ (ed) 2006, Keeping Culture: Aboriginal Tasmania, National Museum of Australia Press, Canberra.

Reynolds, H 1995, Fate of a Free People, Penguin, Melbourne.

- 1999, Why Weren't We Told? A Personal Search for the Truth about Our History, Viking, Ringwood, Victoria.

Rolls, M 2003, 'Why I don't want to be an "ethical" researcher: a polemical paper', Australian Humanities Review, Jan-March, accessed 29 December 2008: <http:// www.australianhumanitiesreview.org/archive/Issue-Jan-2003/rollsl.html>

Rose, DB 2004, Reports from a Wild Country: Ethics for Decolonisation, Universiy of New South Wales Press, Sydney.

Rose, J 2003, On Not Being Able to Sleep: Psychoanalysis and the Modern World, Princeton University Press, Princeton.

— 2007, The Last Resistance, Verso, London.

Rudd, K 2008, 'Apology To Australia's Indigenous Peoples', House of Representatives, Parliament House, Canberra, accessed 13 February 2008: $<$ http//://www.aph.gov.au/house/Rudd_Speech.pdf $>$

Russell, C 1999, Experimental Ethnography: The Work of Film in the Age of Video, Duke University Press, Durham.

Ryan, L 1996[1981], The Aboriginal Tasmanians, Allen \& Unwin, St Leonards, New South Wales.

Santner, E 1990, Stranded Objects: Mourning, Memory, and Film in Postwar Germany, Cornell University Press, Ithaca.

Saxon, PX 2006, The Hands of White Man's Destruction (painting), 'Walk on the Dark Side' (exhibition), School of Fine Arts, University of Newcastle, New South Wales.

Stanner, WEH 1979, White Man Got No Dreaming: Essays 1938-1973, Australian National University Press, Canberra. 
Sullivan, S 2006, Revealing Whiteness: The Unconscious Habits of Racial Privilege, Indiana University Press, Bloomington.

Volkan, V 2006, Killing in the Name of Identity: A Study of Bloody Conflicts, Charlottesville, Pitchstone Publishing, Virginia.

Watson, I 2007, 'Settled and unsettled spaces: are we free to roam?', in Sovereign Subjects: Indigenous Sovereignty Matters, A Moreton-Robinson (ed), Allen \& Unwin, Crows Nest, New South Wales: 15-32.

Watson S 2005, 'The politics of Indigenous resistance in Australia', 3rd Asian Pacific International Solidarity Conference, 26 March 2005, Sydney.

West, I 1984, Pride against Prejudice: Reminiscences of a Tasmanian Aborigine, Australian Institute of Aboriginal Studies, Canberra.

\section{Films}

The Balanda and the Bark Canoes 2006, M Reynolds, T Nehme, R de Heer, Film Australia, Sydney.

Black Man's Houses 1992, S Thomas, Ronin Films, Canberra.

First Australians 2008, R Perkins and D Dale, Blackfella Films and SBS Australia, Sydney.

For Love or Money: a history of women and work in Australia 1983, M McMurchy, M Oliver, M Nash and J Thornley, Ronin Films, Canberra.

Heimat 1984, E Reitz, Facets Multimedia, Germany.

Hitler, A film from Germany 1977, HJ Syberberg, Germany, Facets Multimedia.

Germany Pale Mother 1980, H Sanders-Brahms, Facets Multimedia, Germany.

Island Home Country 2008, J Thornley, Anandi Films, Sydney and The Education Shop, Victoria.

Jindabyne 2006, R Lawrence, Sony, Australia.

The Last Tasmanian 1978, T Haydon, Ronin Films, Canberra.

Maidens 1978, J Thornley, Anandi Films, Sydney.

Night and Fog 1955, A Resnais, Criterion, France.

Portrait of a Distant Land 2008, M Cummins, Roar Films, Hobart.

Rabbit Proof Fence 2002, P Noyce, Orchard, Australia. 
Passionate Histories

Sans Soleil 1983, C Marker, Criterion, France.

Shoah 1985, C Lanzmann, New Yorker Video, France.

Ten Canoes 2006, R de Heer, Vertigo Productions, Australia. 